\title{
A cohort study of Gorlin syndrome with emphasis on standardised phenotyping and quality of life assessment
}

\author{
Aamira J. Huq ${ }^{1}$, Michael Bogwitz ${ }^{1}$, Alexandra Gorelik ${ }^{2}$, Ingrid M. Winship ${ }^{1,3}$, Susan M. \\ White $^{4,5}$, Alison H. Trainer ${ }^{1,3}$ \\ ${ }^{1}$ Department of Genetic Medicine, Royal Melbourne Hospital, Parkville, VIC 3050, Australia \\ ${ }^{2}$ Melbourne EpiCentre, Royal Melbourne Hospital, Parkville, VIC 3050, Australia \\ ${ }^{3}$ Department of Medicine, University of Melbourne, Parkville, 3010, Australia \\ ${ }^{4}$ Victorian Clinical Genetics Services, Murdoch Childrens Research Institute, Parkville, VIC 3052, Australia \\ ${ }^{5}$ Department of Paediatrics, University of Melbourne, Parkville, 3052, Australia
}

\section{Author Details:}

Dr. Aamira Jabeen Huq: Clinical Geneticist, Familial Cancer Centre, Austin Health, Heidelberg 3084; PhD Candidate, Department of Medicine, University of Melbourne, Parkville, 3010, Australia; Honorary Clinical Geneticist, Department of Genetic Medicine, Royal Melbourne Hospital, Parkville, VIC 3050, Australia

Dr. Michael Bogwitz: Genetic Counsellor, Department of Genetic Medicine, Royal Melbourne Hospital, Parkville, VIC 3050, Australia

Alexandra Gorelik: Statistician, Melbourne EpiCentre, Royal Melbourne Hospital, Parkville, VIC 3050, Australia

Prof. Ingrid Margaret Winship: Consultant Clinical Geneticist, Head of Clinical Genetics, Department of Genetic Medicine, Royal Melbourne Hospital, Parkville, VIC 3050, Australia; Executive Director of Research, The Royal Melbourne Hospital, Parkville, VIC 3050, Australia; Professor of Genetics, Department of Medicine, University of Melbourne, Parkville, 3010, Australia

A/Prof. Susan M. White: Consultant Clinical Geneticist, Victorian Clinical Genetics Services, Murdoch Childrens Research Institute, Parkville, VIC 3052, Australia; Honorary Lecturer, Department of Paediatrics, University of Melbourne, Parkville, 3052, Australia

A/Prof. Alison H Trainer: Consultant Clinical Geneticist, Department of Genetic Medicine, Royal Melbourne Hospital, Parkville, VIC 3050, Australia; Consultant Clinical Geneticist, Peter MacCallum Cancer Centre, Melbourne, VIC 3000; Honorary Lecturer, Department of Medicine, University of Melbourne, Parkville, 3052, Australia

Corresponding Author: Dr. Aamira Huq, Postal address: Department of Genetic Medicine, Level 2 Centre, Royal Melbourne Hospital, Parkville, VIC 3050, Australia, e-mail: aamira.huq@mh.org.au, Phone: 0393427151

Conflicts of Interest: The authors declare no conflicts of interest

Word Count: Abstract: 237 Main Text: 3047 (excluding tables, figures and legends)

This is the author manuscript accepted for publication and has undergone full peer review but has not been through the copyediting, typesetting, pagination and proofreading process, which may lead to differences between this version and the Version of Record. Please cite this article as doi: $10.1111 / \mathrm{imj} .13429$

This article is protected by copyright. All rights reserved. 


\section{Abstract:}

Background:

Gorlin syndrome (Nevoid Basal Cell Carcinoma Syndrome) is a rare genetic predisposition to basal cell carcinomas (BCCs), keratocysts of the jaw and calcification of the falx cerebri amongst other clinical features. With the advent of sonic hedgehog inhibitors for the treatment of BCCs, it is timely to establish a cohort of individuals with Gorlin syndrome and collect standardised phenotypic information on these individuals. Moreover, the health-related quality of life (QoL) in individuals with Gorlin syndrome is not well studied. We aimed to establish a Victorian cohort of Gorlin syndrome and study the QoL in these individuals.

Methods:

Phenotypic data was obtained by reviewing medical records of individuals attending two major tertiary/quaternary genetic referral centres in Victoria, followed by telephone or face to face interviews where possible. QoL information was obtained utilising an AQoL-6D quality of life survey form.

Results:

The median number of BCCs in the 19 individuals studied was 17.5 (IQR 3-70). The number of patients with $\geq 100 \mathrm{BCCs}$ in this group was similar to a previously described national cohort $(22.2 \% \mathrm{vs}$ $27 \%$, respectively). Fifty-eight percent of referrals to the genetics clinics originated from maxillofacial surgeons and $42 \%$ from dermatologists. Individuals with $\geq 100 \mathrm{BCCs}$ had worse median QoL scores compared to those with $<100$ BCCs ( 36 vs 29 , p value 0.031 )

\section{Conclusions:}

The clinical features in our cohort were congruent with those previously described in Australia. The QoL is adversely correlated with increased BCC burden.

Key Words: Nevoid Basal Cell Carcinoma Syndrome, NBCCS, Basal Cell Nevus Syndrome, Gorlin Syndrome, Gorlin-Goltz syndrome, Basal Cell Carcinomas, BCC, Quality of life in Gorlin syndrome, PTCH1, SUFU 


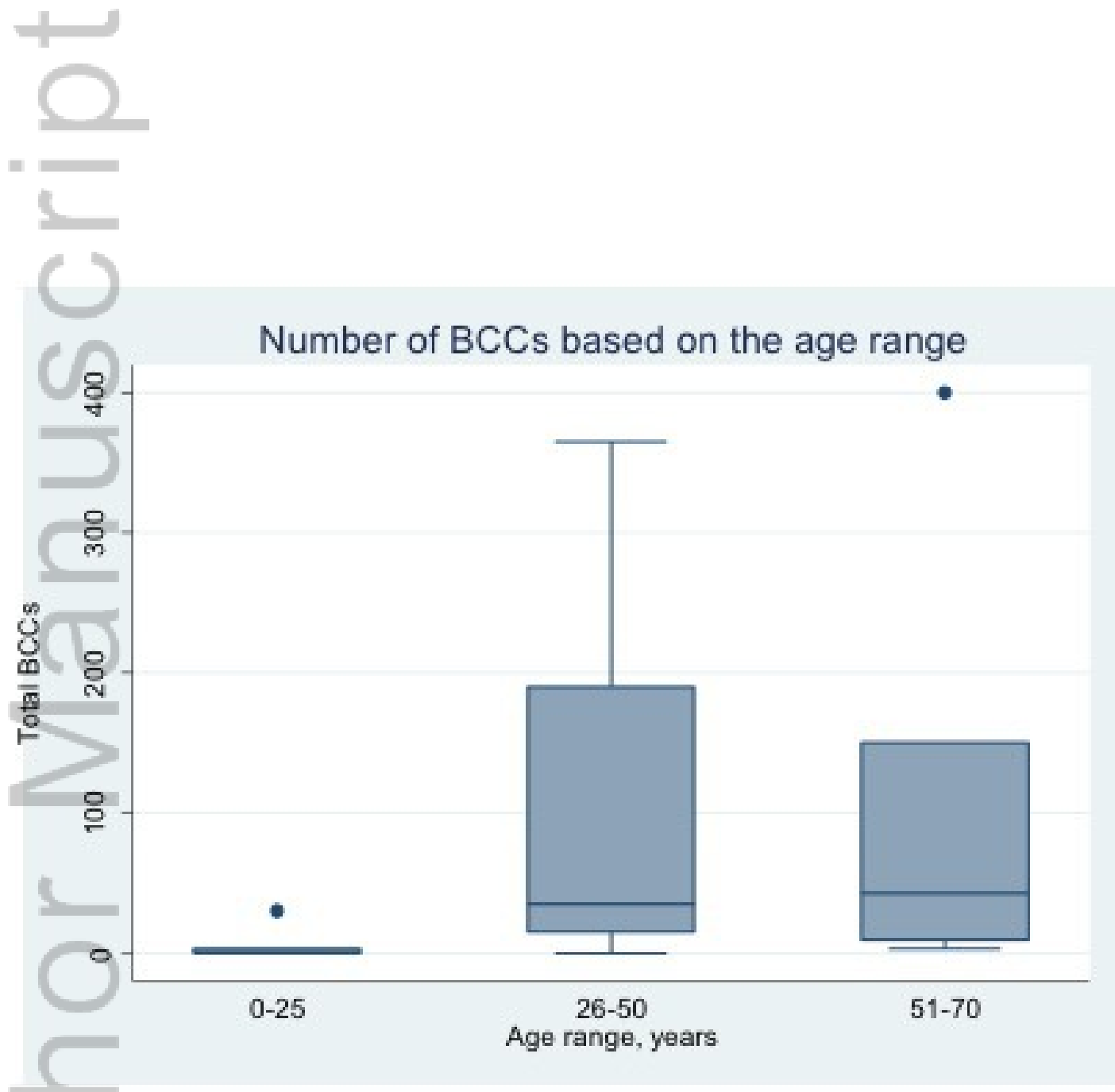

Figure 1.jpg

This article is protected by copyright. All rights reserved. 


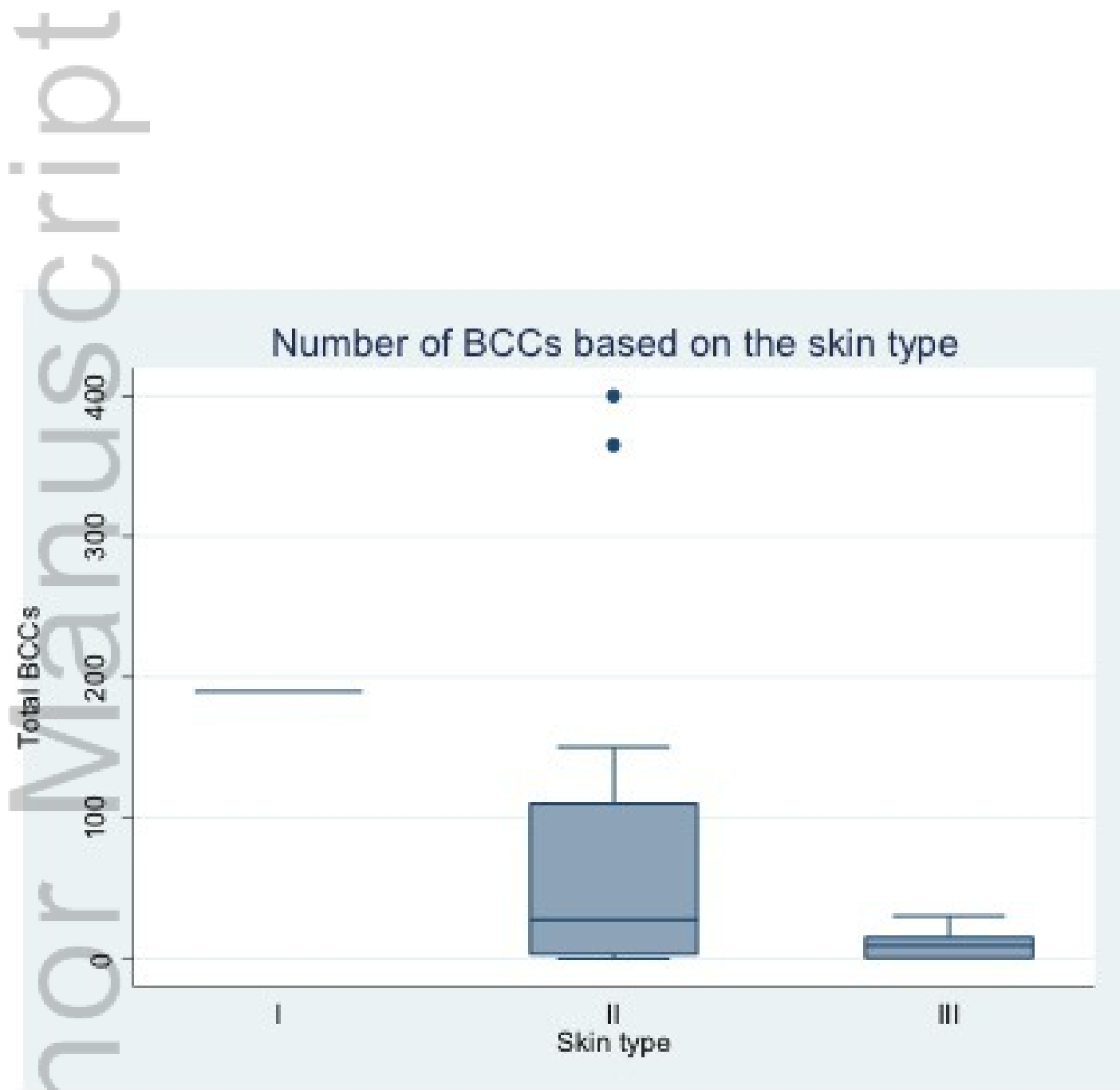

Figure 2.jpg

This article is protected by copyright. All rights reserved. 

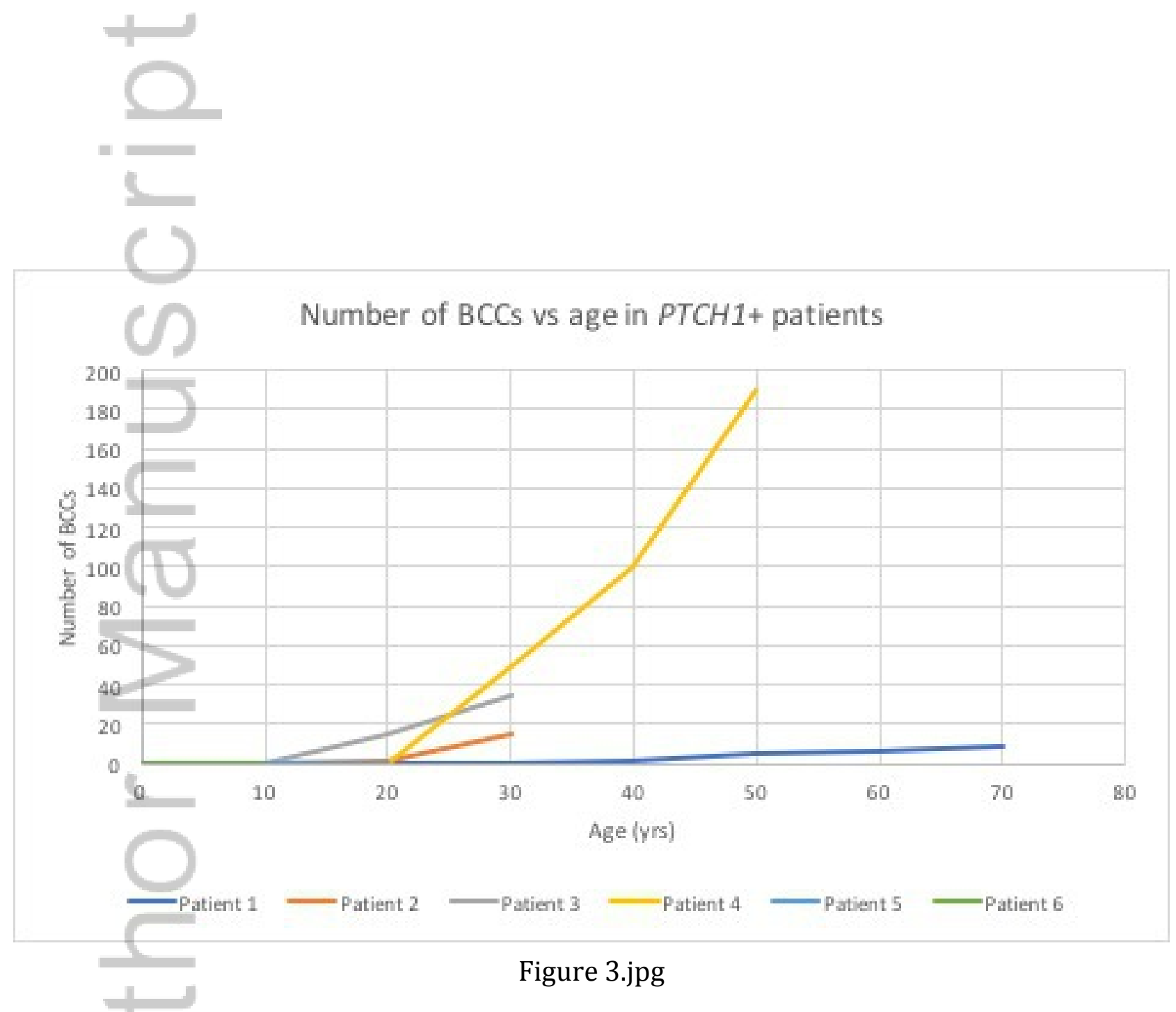

Figure 3.jpg

This article is protected by copyright. All rights reserved. 


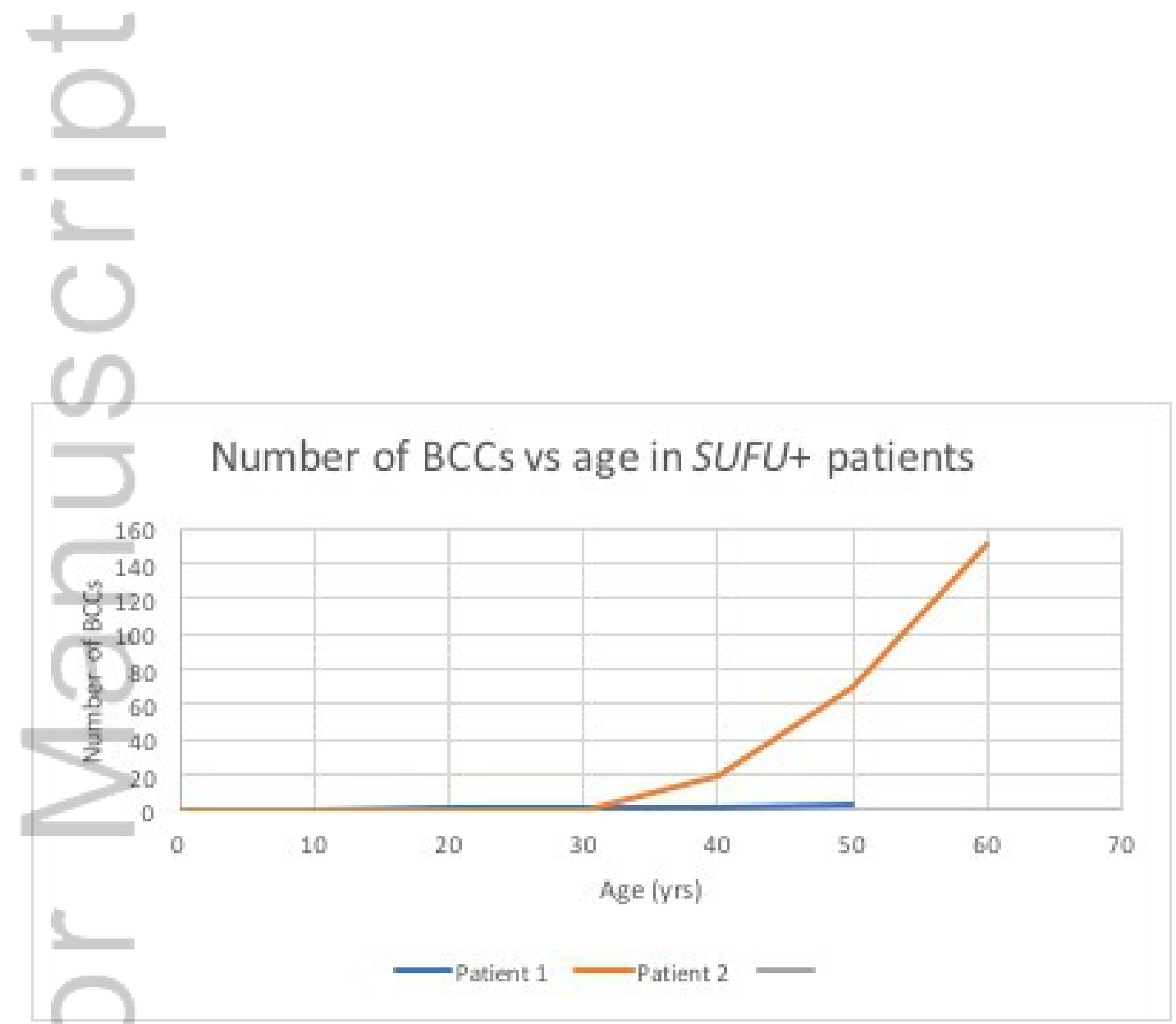

Figure 4.jpg

This article is protected by copyright. All rights reserved. 


\section{A cohort study of Gorlin syndrome with emphasis on standardised}

\section{phenotyping and quality of life assessment}

\section{Background and introduction:}

Gorlin syndrome, also known as the nevoid basal cell carcinoma syndrome (NBCCS), is an autosomal dominant developmental syndrome, which causes various congenital abnormalities and a predisposition to basal cell carcinomas (BCCs) ${ }^{1,2}$. The condition is highly penetrant, however, the clinical features can be variable ${ }^{3}$. The Australian prevalence, ascertained on clinical criteria, was estimated in 1994 as $1: 164,000^{4}$.

There are two currently used clinical criteria for the diagnosis of Gorlin syndrome (Table 1) ${ }^{2,5}$.

Table 1

A mutation in the gene PTCH1 accounts for $50-90 \%$ of cases $^{6,7}$, with the other implicated genes being SUFU ${ }^{8}$ and $P T C H 2{ }^{9}$. Approximately $15-27 \%$ of clinical cases do not have a detectable mutation ${ }^{10}$. The gene product of $P T C H 1$ acts as a tumour suppressor in the hedgehog signalling pathway, and abrogation of this pathway explains the increased propensity for BCCs ${ }^{11-15}$.

Our study aimed to phenotypically annotate a Victorian cohort of individuals with Gorlin syndrome. It is well recognized that proximity to equator increases the risk for skin cancers ${ }^{16-19}$. Therefore, with possibly less UV exposure in Victoria in comparison to the northern states, we aimed to assess the BCC burden in Victorian patients. Visible skin lesions, particularly on the face, have been associated 
with depression and reduced quality of life (QoL) ${ }^{20-22}$. We report health related QoL in this cohort correlated with the clinical features with particular reference to the number of BCCs.

\section{Methods:}

\section{Study sites and ethical oversight:}

Human Research Ethics Committees at Melbourne Health (MH) and the Royal Children's Hospital $(\mathrm{RCH})$ have reviewed and approved the study (MH project number: 2013.314, $\mathrm{RCH}$ project number: HREC 34283A).

Inclusion and exclusion criteria:

Database searches were conducted in Melbourne Health Department of Genetics, including the Familial Cancer Centre (FCC), and The Victorian Clinical Genetics Services (VCGS). All individuals who attended these two genetic centres and were clinically diagnosed with Gorlin syndrome based on the above criteria or otherwise clinically suspected to have Gorlin syndrome by a geneticist were included. Potential adult participants who were unable to consent to the study, deceased participants with no next of kin and children without a parent to consent were excluded. Individual file reviews were conducted and participants were also surveyed over the phone to obtain more details of their medical history. Patients who attended the FCC and thus recruited were clinically assessed at their appointment after written informed consent was obtained.

\section{Data collection:}

Information on skin type was collected based on skin colour and tanning ability and translated to the Fitzpatrick skin-type scale (see appendix 1$)^{23}$. We chose to ascertain QoL using the AQoL-6D questionnaire as Australian population norms for this questionnaire were available ${ }^{24}$. The QoL questionnaire ascertains the patient's self-reported current health-related QoL. It was undertaken retrospectively and does not reflect the participants' QoL at the time of diagnosis, genetic testing or BCC surgery.

This article is protected by copyright. All rights reserved. 


\section{Genetic testing:}

The majority of $P T C H 1$ testing was performed through Sanger sequencing although the more recent tests were performed through next generation sequencing and Sanger verification of variants. Copy number variant analysis on all samples was undertaken either through MLPA or CGH-array based techniques by the testing laboratory.

All SUFU tests were done through massively parallel sequencing with variants confirmed by Sanger sequencing in addition to QMPS or CGH-array based copy number variation analysis by the testing laboratory.

\section{Statistical analysis:}

Descriptive analysis was undertaken and results reported as median with interquartile range (IQR) for continuous data and $\mathrm{n}(\%)$ for categorical data. Wilcoxon rank-sum test was used to determine any associations between total number of BCCs or QoL, and the various categorical variables such as mutation status, sun exposure, jaw cysts, occupation. Spearman's correlation was used to determine an association between total number of BCCs and patients' QoL. Fisher's exact test was used to determine any associations between PTCH1 mutation and patient's clinical characteristics. Level of significance was set at $p<0.05$ for all tests. The data analysis was performed using Stata12 (StataCorp, College station, TX, USA).

\section{Results:}

\section{Cohort demographics:}

Nineteen patients (12 from MH and 7 from VCGS) were recruited to the study. Demographic characteristics of the study cohort are presented in table 2 . There were 2 families each with 3 affected members, whilst the other participants were unrelated. The median age at diagnosis of Gorlin syndrome was 18 (IQR 14-55).

This article is protected by copyright. All rights reserved. 
Table 2

The majority of genetic referrals originated from maxillofacial surgeons $(57.9 \%, 11 / 19)$ and the remainder $(42.1 \%, 8 / 19)$ from dermatologists. Eight individuals were diagnosed with Gorlin syndrome either at or before the age of 18 with 7 of them diagnosed by maxillofacial surgeon. There were 3 patients who did not fulfil either diagnostic criteria, however, underwent genetic testing due to the presence of multiple BCCs or jaw cysts.

\section{Clinical features:}

Table 3

\section{Basal cell carcinomas:}

Seven out of the 8 male participants (87.5\%) and 7 out of 10 females $(70 \%)$ had a history of BCCs. (BCC data was unavailable in one female). The median number of BCCs in this cohort was 17.5 , with a median of 5 on the face and 12.5 on the body. Of the 6 participants aged $\leq 25$, three had not developed BCCs yet, one had 3 and one had 30 BCCs. No data on BCCs were available for one young participant. The cumulative number of BCCs with age is depicted in figure 1. The median number of BCCs in our cohort was 0 under the age of 25, 35 between the ages 26 and 50, 42.5 between ages 51 and 70. The youngest age of onset of BCCs was 12 years in a man who has subsequently developed 30 BCCs by his current age of 25 . The 4 individuals with documented absence of BCCs are all 
currently aged less than 30 . The number of BCCs in PTCH1 and SUFU mutation positive individuals with increasing age is depicted in figures 3 and 4 .

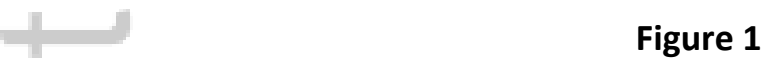

Distribution of BCCs based on Fitzpatrick skin type is depicted in figure 2.

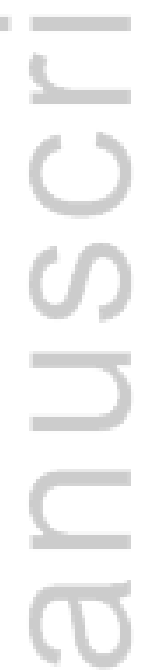

Figure 2

Figure 3

Figure 4

There were 4 individuals who had $>100$ BCCs. Their characteristics are listed in table 4 . All 4 fulfilled both Evans and Kimonis diagnostic criteria for Gorlin syndrome.
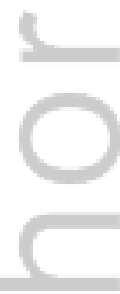

च

Table 4

Jaw cysts:

Odontogenic keratocysts were the second most common feature, being present in 12 of the 19

(63.2\%) participants. Eleven patients were referred to the genetic clinic by maxillofacial surgeons and one patient (developed his first BCC at the age of 12) was referred by his dermatologist.

This article is protected by copyright. All rights reserved. 
All individuals with jaw cysts fulfilled the clinical diagnostic criteria except one, who was tested on the basis of isolated jaw cysts. Seven out of 12 underwent genetic testing for PTCH1 with 5 of these participants having a pathogenic mutation.

Seven of the 12 participants with jaw cysts also had BCCs. The most jaw cysts described was 20 in a 22 year old female whose diagnosis of Gorlin syndrome was made at the age of 8 due to multiple jaw cysts and medulloblastoma. She has not developed BCCs and has not undergone genetic testing to date.

Palmar and plantar pits:

All 10 patients with >3 palmar/plantar pits fulfilled the clinical diagnostic criteria. Nine of these participants also had jaw cysts and 7 had BCCs. Five underwent genetic testing of PTCH1 and a pathogenic mutation was identified in all cases.

Calcification of the falx:

Calcification of falx was seen in $64.3 \%(9 / 14)$ of the participants. Of these, 7 were female and 2 were male. All participants with falx calcification fulfilled the clinical diagnostic criteria. Five of these nine participants with falx calcification underwent genetic testing, with 2 found to harbour a PTCH1 mutation and 2 found to have SUFU mutations.

Other features:

A family history of Gorlin syndrome, diagnosed clinically in at least one first degree relative was present in $8 / 17$ (47.1\%) participants. Macrocephaly, present in 10/15 (66.7\%) participants, was the commonest of the minor Evans/ Kimonis diagnostic features. Four of the 19 participants (21.1\%) had a high arched palate. Scoliosis was present in 7/17 (41.2\%) individuals. 9/15 (60\%) participants reported childhood fractures. 3 participants had mild intellectual disability. Medulloblastoma was present in one patient.

Genetic testing results:

This article is protected by copyright. All rights reserved. 
Eleven out of nineteen (68.4\%) participants underwent genetic testing for PTCH1. Six of the 11 patients tested (54.5\%) were found to have a pathogenic PTCH1 mutation and 5 did not. Two participants were not offered testing but were categorised as PTCH1 -ve as their similarly clinically affected sibling had no PTCH1 mutation on testing.

Two unrelated patients who did not harbour a PTCH1 mutation were found to have a mutation in SUFU. The characteristics of the PTCH1 mutation-positive patients compared to those with negative results are listed in table 5. There were 4 different PTCH1 mutations and 2 different SUFU mutations identified in the cohort.

\section{Table 5}

Presence of palmar/plantar pits was the only clinical feature that reached statistical significance between the PTCH1 +ve and PTCH1 -ve groups ( $p$ value of 0.005$)$.

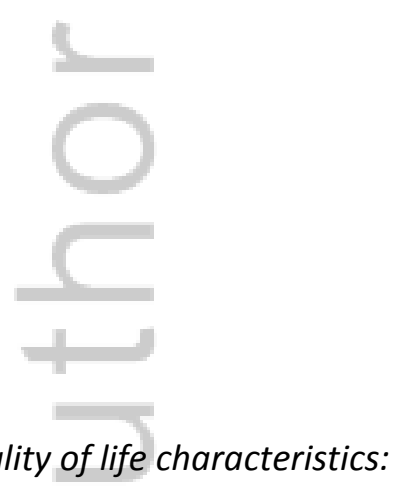

Table 6

The AQoL-6D questionnaire is designed to assess health related QoL in adults only. Four participants were excluded from this analysis, due to either being $<18$, having a mild intellectual disability, being deceased or having circumstances which would independently impact on QoL.

This article is protected by copyright. All rights reserved. 
The overall and age-based QoL scores were calculated on a weighted scale to enable comparison with population norms. In the weighted scales, scores closer to 1.0 reflect good health related QoL outcomes and scores closer to 0 reflect worse outcomes. Raw scores were used to calculate the QoL scores for all other features and compared within the cohort as no population norms were available for these features. When using the raw scores, higher scores reflect worse QoL outcomes. The AQoL6D survey questionnaire can be divided into 6 different dimensions based on the questions in the survey. Table 6 compares age related QoL scores and the various dimensions with the population norms. In summary, there were no statistically significant differences between our cohort and the population norms.

Table 7

Multiple variables were compared between the different participants within the cohort as mentioned in table 7 . The only variable that reached statistical significance within this cohort was presence of $\geq 100$ BCCs, when compared with individuals with $<100$ BCCs ( $p$ value $=0.031$ ). Individuals with scoliosis had lower QoL scores compared with those who did not have scoliosis ( $\mathrm{p}$ value $=0.08)$.

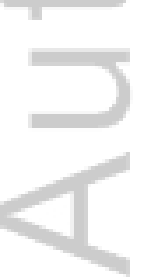

Table 8

\section{Discussion:}

In this study we have collected standardized phenotyping information on a Victorian cohort with Gorlin syndrome, and analysed the health related QoL associated with the diagnosis.

This article is protected by copyright. All rights reserved. 


\section{Phenotypic information:}

BCCs in the cohort:

The background rate of BCCs is very high in the Australian general population with a reported incidence of 884 per 100,000 person-years as recorded in $2002^{26}$. The incidence of basal cell carcinomas (BCCs) in Gorlin syndrome varies significantly between individuals and can range from several hundred to relatively few, but they tend to occur at an earlier age and higher frequency than in the average population ${ }^{27}$. Within Australia, the rates of non-melanoma skin cancer (NMSC) varies with latitude ${ }^{28}$. The prevalence of NMSC in Queensland recorded between 1986 and 1987 was $5 \%{ }^{17}$. However, as BCCs are not reportable to cancer registry in Australia, the numbers of BCCs nationwide were difficult to obtain. The prevalence of BCCs in our cohort $(77.8 \%)$ is concordant with the numbers reported by Shanley et al in a large Australian cohort ${ }^{4}$, although we acknowledge that with our small numbers, no definite conclusions can be made. Interestingly, in our cohort, the median number of BCCs in patients with a PTCH1 mutation did not vary from those without a PTCH1 mutation.

All people in this study had Fitzpatrick skin type I-III with most common being type II. Therefore, this study is more representative of the Caucasian population and the BCC numbers cannot be translated to other skin types or ethnic backgrounds. It is important to note that we only had one patient with Fitzpatrick type I skin. Therefore the high number of BCCs seen in this individual is not necessarily representative of all Gorlin syndrome patients with type I skin.

Childhood sun exposure has a stronger association with later BCC development compared to adult sun exposure ${ }^{29}$. We looked at the impact of high versus low childhood sun exposure on the number of BCCs. The confounding factor in our cohort was that the mean age of the low childhood sun exposure group was significantly lower, being 24 , than the high childhood sun exposure group, being 43.5. It is not possible to predict if this younger population will develop more BCCs with time.

This article is protected by copyright. All rights reserved. 
Therefore, it is difficult to draw conclusions on the effect of childhood sun exposure from this cohort.

We have shown in Figure 1 the trend towards the increase of total number of BCCs with ageing in patients with Gorlin syndrome $(p=0.066)$. This could statistically be proven in a larger cohort.

Other features:

As odontogenic keratocysts are a unique finding, this prompts specialist referral earlier with a potentially earlier diagnosis in comparison to BCCs which are more common in the population and therefore likely to be managed without a specialist referral. In keeping with the lack of genotype phenotype correlation described with PTCH1 mutations in the literature ${ }^{30}$, in our cohort, a father with a PTCH1 mutation had $9 \mathrm{BCCs}$ at the age of 70 , whilst one of his daughters had $15 \mathrm{BCCs}$ at the age of 26 and the other had not developed any BCCs at the age of 23. This supports the evidence that modifying genes or environmental factors modify the age of onset of BCCs in Gorlin syndrome ${ }^{31}$. Surprisingly, other than the presence of palmar/plantar pits, no other clinical features were significantly different between the PTCH1+ and PTCH1-ve groups. It is possible that the small numbers in this study has increased the standard error of the mean and masked any differences.

\section{Health related QoL:}

We found that the QoL in our $\leq 25$-year-old participants $(n=6)$ was better than the population norms. One of the factors influencing this may be a selection bias with the cohort formed of patients willing to participate in the study, indicating their interest in their health outcomes. As the phenotypes were similar between the PTCH1+ and PTCH1- patients, the lack of difference in the QoL scores between these two groups was not surprising.

The adverse effect on QoL with scoliosis is worthy of further analysis in a larger cohort as it has been noted in literature that scoliosis negatively affects health related QoL significantly ${ }^{32}$. Evaluating the clinical utility of genetic testing: 
The utility of genetic testing in those who fulfil the diagnostic criteria for Gorlin syndrome is largely to allow predictive testing of family members. Early genotypic diagnosis allows better reinforcement of sun avoidance and recruitment to strict surveillance programs. Conversely, a negative predictive test provides marked reassurance. Some families, depending on the severity and impact of Gorlin syndrome, may choose to explore options such as pre-natal diagnosis or pre-implantation genetic diagnosis.

In patients who do not fulfill the clinical criteria but have some suggestive features, genetic testing may confirm a diagnosis, providing certainty with regards to the diagnosis as well as opening up targeted therapeutic options. In this category, those who do not have a mutation suggestive of Gorlin syndrome present a diagnostic and management challenge. As there are some age related manifestations of Gorlin syndrome, the surveillance in these patients should be individualized based on their clinical features at the time of review.

A SUFU mutation should be suspected in Gorlin syndrome families with a history of medulloblastoma and macrocephaly ${ }^{33}$. The utility in offering SUFU genetic testing is high in such families as surveillance through annual brain MRI may be relevant in children with a mutation in this gene ${ }^{10}$.

\section{Surveillance and follow-up:}

The number of participants in this study was smaller than expected due to loss of contact with many paediatric cases when they transitioned to adult care. This raises the issue of awareness and education of primary care physicians whose clinics these patients are likely to continue to attend and seek advice from. The majority of BCCs are likely to be diagnosed and treated by General Practitioners. We suggest that primary care physicians should be educated about the genetic nature of this condition and the clinical diagnostic criteria. It is particularly important as this may facilitate identification of other family members who may be at risk so they can make informed choices in terms of occupational or recreational sun exposure as well as genetic testing. 


\section{Limitations:}

The number of participants in this study was small. In addition, the retrospective nature of this study meant that not all data-fields could be collected in all individuals.

\section{Conclusions:}

In conclusion, the number of people with $>100$ BCCs in this Victorian subpopulation of Gorlin syndrome patients was not significantly different to the national average for this condition, despite the difference in the solar ultraviolet radiation exposure due to the latitude differences. The clinical features in our cohort were congruous with those previously described in Australia.

The quality of life is adversely affected by the number of BCCs, however, this needs to be verified in a larger study as the numbers were small. General practitioners need to be educated about the features of Gorlin syndrome to aid in earlier diagnosis and treatment. The relationship between QoL and scoliosis needs to be examined further.

\section{Future Directions:}

Collection of a cohort of patients with Gorlin syndrome with standardized phenotypic information is highly relevant in the current era of therapeutic trials for BCCs in Gorlin syndrome such as oral and topical sonic hedgehog inhibitors ${ }^{34-37}$. This well annotated clinical cohort can be drawn upon for future trials. Patients with jaw cysts could potentially benefit from any future trials of sonic hedgehog inhibitors for keratocysts in Gorlin syndrome such as described by Goldberg et $\mathrm{al}^{37}$. The current study has been set up as a platform for a future study of a Victorian cohort which could act as a registry for therapeutic studies. The data held in the registry would form a baseline, so that metrics could be devised to measure response to treatment accordingly. 


\section{References:}

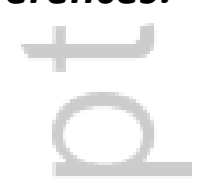

1. Lo Muzio L. Nevoid basal cell carcinoma syndrome (Gorlin syndrome). Orphanet journal of rare diseases. 2008;3:32.

2. Evans DG, Ladusans EJ, Rimmer S, Burnell LD, Thakker N, Farndon PA. Complications of the naevoid basal cell carcinoma syndrome: results of a population based study. J Med Genet. Jun 1993;30(6):460-464.

3. Kiwilsza M, Sporniak-Tutak K. Gorlin-Goltz syndrome--a medical condition requiring a multidisciplinary approach. Medical science monitor : international medical journal of experimental and clinical research. Sep 2012;18(9):RA145-153.

4. Shanley S, Ratcliffe J, Hockey A, et al. Nevoid basal cell carcinoma syndrome: review of 118 affected individuals. Am J Med Genet. Apr 15 1994;50(3):282-290.

5. Kimonis VE, Goldstein AM, Pastakia B, et al. Clinical manifestations in 105 persons with nevoid basal cell carcinoma syndrome. American journal of medical genetics. Mar 31 1997;69(3):299-308.

6. Evans DG, Farndon PA. Nevoid Basal Cell Carcinoma Syndrome. In: Pagon RA, Adam MP, Ardinger $\mathrm{HH}$, et al., eds. GeneReviews(R). Seattle (WA)1993.

7. Lindstrom E, Shimokawa T, Toftgard R, Zaphiropoulos PG. PTCH mutations: distribution and analyses. Hum Mutat. Mar 2006;27(3):215-219.

8. Pastorino $L$, Ghiorzo $P$, Nasti $S$, et al. Identification of a SUFU germline mutation in a family with Gorlin syndrome. Am J Med Genet A. Jul 2009;149A(7):1539-1543.

9. Fan Z, Li J, Du J, et al. A missense mutation in PTCH2 underlies dominantly inherited NBCCS in a Chinese family. Journal of medical genetics. May 2008;45(5):303-308.

10. Smith MJ, Beetz C, Williams SG, et al. Germline mutations in SUFU cause Gorlin syndromeassociated childhood medulloblastoma and redefine the risk associated with PTCH1 mutations. J Clin Oncol. Dec 20 2014;32(36):4155-4161.

11. Farndon PA, Del Mastro RG, Evans DG, Kilpatrick MW. Location of gene for Gorlin syndrome. Lancet. Mar 7 1992;339(8793):581-582.

12. Hahn H, Wicking C, Zaphiropoulous PG, et al. Mutations of the human homolog of Drosophila patched in the nevoid basal cell carcinoma syndrome. Cell. Jun 14 1996;85(6):841-851.

13. Johnson RL, Rothman AL, Xie J, et al. Human homolog of patched, a candidate gene for the basal cell nevus syndrome. Science. Jun 14 1996;272(5268):1668-1671.

14. Gailani MR, Bale SJ, Leffell DJ, et al. Developmental defects in Gorlin syndrome related to a putative tumor suppressor gene on chromosome 9. Cell. Apr 3 1992;69(1):111-117.

15. Levanat S, Gorlin RJ, Fallet S, Johnson DR, Fantasia JE, Bale AE. A two-hit model for developmental defects in Gorlin syndrome. Nature genetics. Jan 1996;12(1):85-87.

16. Bauer A, Diepgen TL, Schmitt J. Is occupational solar ultraviolet irradiation a relevant risk factor for basal cell carcinoma? A systematic review and meta-analysis of the epidemiological literature. Br J Dermatol. Sep 2011;165(3):612-625. 
17. Green A, Beardmore G, Hart V, Leslie D, Marks R, Staines D. Skin cancer in a Queensland population. J Am Acad Dermatol. Dec 1988;19(6):1045-1052.

18. English DR, Kricker A, Heenan PJ, Randell PL, Winter MG, Armstrong BK. Incidence of nonmelanocytic skin cancer in Geraldton, Western Australia. Int J Cancer. Nov 27 1997;73(5):629-633.

19. Marks R, Jolley D, Dorevitch AP, Selwood TS. The incidence of non-melanocytic skin cancers in an Australian population: results of a five-year prospective study. Med J Aust. May 1 1989;150(9):475-478.

20. Ghajarzadeh M, Ghiasi M, Kheirkhah S. Associations between skin diseases and quality of life: a comparison of psoriasis, vitiligo, and alopecia areata. Acta Med Iran. 2012;50(7):511515.

21. Tidman MJ. Prompt treatment of acne improves quality of life. Practitioner. Jun 2012;256(1752):15-17, 12.

22. Mathias SD, Chren MM, Colwell HH, et al. Assessing health-related quality of life for advanced basal cell carcinoma and basal cell carcinoma nevus syndrome: development of the first disease-specific patient-reported outcome questionnaires. JAMA Dermatol. Feb 2014;150(2):169-176.

23. Fitzpatrick TB. The validity and practicality of sun-reactive skin types I through VI. Arch Dermatol. Jun 1988;124(6):869-871.

24. Richardson JR, Peacock SJ, Hawthorne G, lezzi A, Elsworth G, Day NA. Construction of the descriptive system for the Assessment of Quality of Life AQoL-6D utility instrument. Health Qual Life Outcomes. 2012;10:38.

25. Mann K, Magee J, Guillaud-Bataille $M$, et al. Multiple skin hamartomata: a possible novel clinical presentation of SUFU neoplasia syndrome. Fam Cancer. Mar 2015;14(1):151-155.

26. Staples MP, Elwood M, Burton RC, Williams JL, Marks R, Giles GG. Non-melanoma skin cancer in Australia: the 2002 national survey and trends since 1985. The Medical journal of Australia. Jan 2 2006;184(1):6-10.

27. Berlin NI, Van Scott EJ, Clendenning WE, et al. Basal cell nevus syndrome. Combined clinical staff conference at the National Institutes of Health. Annals of internal medicine. Feb 1966;64(2):403-421.

28. Perera E, Gnaneswaran N, Staines C, Win AK, Sinclair R. Incidence and prevalence of nonmelanoma skin cancer in Australia: A systematic review. Australas J Dermatol. Nov 2015;56(4):258-267.

29. Gallagher RP, Hill GB, Bajdik CD, et al. Sunlight exposure, pigmentary factors, and risk of nonmelanocytic skin cancer. I. Basal cell carcinoma. Arch Dermatol. Feb 1995;131(2):157163.

30. Wicking $\mathrm{C}$, Shanley S, Smyth I, et al. Most germ-line mutations in the nevoid basal cell carcinoma syndrome lead to a premature termination of the PATCHED protein, and no genotype-phenotype correlations are evident. Am J Hum Genet. Jan 1997;60(1):21-26.

31. Yasar B, Byers HJ, Smith MJ, et al. Common variants modify the age of onset for basal cell carcinomas in Gorlin syndrome. Eur J Hum Genet. May 2015;23(5):708-710.

32. Freidel K, Petermann F, Reichel D, Steiner A, Warschburger P, Weiss HR. Quality of life in women with idiopathic scoliosis. Spine (Phila Pa 1976). Feb 15 2002;27(4):E87-91.

33. Brugieres $L$, Remenieras A, Pierron $G$, et al. High frequency of germline SUFU mutations in children with desmoplastic/nodular medulloblastoma younger than 3 years of age. $J$ Clin Oncol. Jun 10 2012;30(17):2087-2093.

34. Sekulic A, Migden MR, Oro AE, et al. Efficacy and safety of vismodegib in advanced basal-cell carcinoma. N EnglJ Med. Jun 7 2012;366(23):2171-2179.

35. Tang JY, Mackay-Wiggan JM, Aszterbaum M, et al. Inhibiting the hedgehog pathway in patients with the basal-cell nevus syndrome. N Eng/ J Med. Jun 7 2012;366(23):2180-2188. 
36. Saran A. Basal cell carcinoma and the carcinogenic role of aberrant Hedgehog signaling. Future Oncol. Jun 2010;6(6):1003-1014.

37. Goldberg LH, Landau JM, Moody MN, Kazakevich N, Holzer AM, Myers A. Resolution of odontogenic keratocysts of the jaw in basal cell nevus syndrome with GDC-0449. Arch Dermatol. Jul 2011;147(7):839-841.

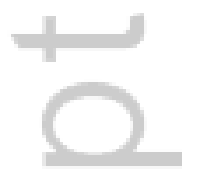

\section{Figure Legends}

Figure 1: Cumulative number of BCCs against age

Figure 2: Median number of BCCs based on Fitzpatrick skin type

Figure 3: Cumulative number of BCCs with age in individual PTCH1 mutation positive patients.

Note: Patients 5 and 6 have not developed any BCCs to their respective ages of 23 and 15.

Figure 4: Cumulative number of BCCs with age in individual SUFU mutation positive patients

This article is protected by copyright. All rights reserved. 


\section{Tables}

Table 1: Clinical diagnostic criteria

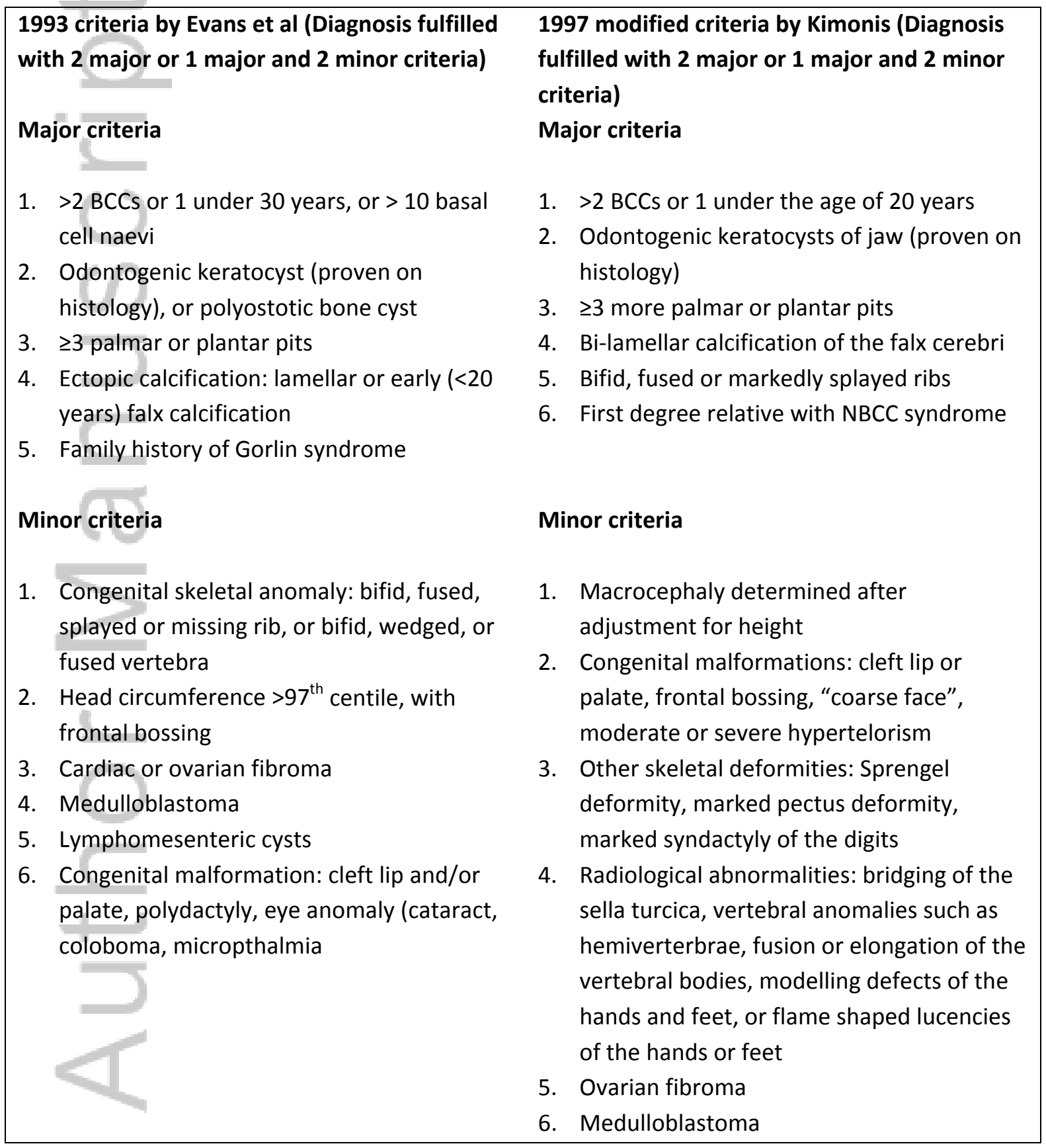

This article is protected by copyright. All rights reserved. 
Table 2: Demographics

\begin{tabular}{|c|c|c|}
\hline Total & & $n=19$ \\
\hline \multicolumn{3}{|c|}{ Gender } \\
\hline & Male (\%) & $8(42.1)$ \\
\hline & Female (\%) & $11(57.9)$ \\
\hline \multicolumn{2}{|c|}{ Age at recruitment, mean (SD) } & $38.6(17.8)$ \\
\hline & $<18$ & $1(5.3)$ \\
\hline & $\geq 18$ & $18(94.7)$ \\
\hline \multicolumn{3}{|c|}{ Ethnicity } \\
\hline & Caucasian (\%) & $12(63.2)$ \\
\hline & Other (\%) & $7(36.8)$ \\
\hline \multicolumn{3}{|c|}{ Occupation } \\
\hline & Indoor (\%) & $16(84.2)$ \\
\hline & Outdoor (\%) & $2(10.5)$ \\
\hline & Missing (\%) & $1(5.3)$ \\
\hline \multicolumn{3}{|c|}{ Relationship status } \\
\hline & d/ de-facto (\%) & $13(68.4)$ \\
\hline & Single (\%) & $5(26.3)$ \\
\hline & Child (\%) & $1(5.3)$ \\
\hline \multicolumn{3}{|c|}{ Smoking } \\
\hline & Current (\%) & $1(5.3)$ \\
\hline & Past (\%) & $6(31.5)$ \\
\hline & Never (\%) & $11(57.9)$ \\
\hline & Missing (\%) & $1(5.3)$ \\
\hline \multicolumn{3}{|c|}{ Fitzpatrick Skin Type } \\
\hline & Type I (\%) & $1(5.3)$ \\
\hline & Type II (\%) & $12(63.2)$ \\
\hline & Type III (\%) & $5(26.2)$ \\
\hline & Type IV-VI (\%) & $0(0)$ \\
\hline & Missing (\%) & $1(5.3)$ \\
\hline \multicolumn{3}{|c|}{ Childhood sun exposure* } \\
\hline & High (\%) & $11(57.9)$ \\
\hline & Low (\%) & $5(26.3)$ \\
\hline & Missing (\%) & $3(15.8)$ \\
\hline
\end{tabular}

*self reported

This article is protected by copyright. All rights reserved. 
Table 3: Predominant Evans or Kimonis criteria features in the cohort

\begin{tabular}{|cc|}
\hline Clinical features & Numbers $^{*}$ (\%) \\
Basal Cell Carcinomas & $14 / 18(77.8)$ \\
Macrocephaly & $10 / 15(66.7)$ \\
Odontogenic keratocyst (Jaw cyst) & $12 / 19(63.2)$ \\
Palmar/plantar pits & $10 / 18(55.6)$ \\
Calcification of falx & $9 / 14(64.3)$ \\
Family history of Gorlin syndrome & $8 / 17(47.1)$ \\
Scoliosis & $7 / 17(41.2)$ \\
\hline
\end{tabular}

Note: the denominator varies in each category as full clinical information was not available on all 19 participants

This article is protected by copyright. All rights reserved. 
Table 4: Characteristics of individuals with $>100$ BCCs

\begin{tabular}{|c|c|c|c|c|}
\hline$>100 \mathrm{BCCs}$ & Patient 1 & Patient 2 & Patient 3 & Patient 4 \\
\hline $\begin{array}{l}\text { Number on } \\
\text { face }\end{array}$ & 10 & 50 & 200 & 220 \\
\hline $\begin{array}{l}\text { Number on } \\
\text { body }\end{array}$ & 180 & 100 & 200 & 145 \\
\hline Gender & Male & Female & Male & Female \\
\hline $\begin{array}{l}\text { Current } \\
\text { Age }\end{array}$ & 46 & 62 & 55 & 38 \\
\hline $\begin{array}{l}\text { Ethnic } \\
\text { origin }\end{array}$ & Caucasian & Caucasian & Caucasian & Caucasian \\
\hline Skin type & I & II & II & II \\
\hline $\begin{array}{l}\text { Childhood } \\
\text { sun } \\
\text { exposure }\end{array}$ & High & High & High & High \\
\hline $\begin{array}{l}\text { History of } \\
\text { smoking }\end{array}$ & $\mathrm{N}$ & $Y$ & Y & $\mathrm{N}$ \\
\hline $\begin{array}{l}\text { Age } \\
\text { smoking } \\
\text { ceased }\end{array}$ & N/A & 18 & 25 & $\mathrm{~N} / \mathrm{A}$ \\
\hline $\begin{array}{l}\text { Squamous } \\
\text { Cell } \\
\text { Carcinomas }\end{array}$ & 2 & 0 & 1 & 0 \\
\hline $\begin{array}{l}\text { Number of } \\
\text { jaw cysts }\end{array}$ & & 0 & 4 & 3 \\
\hline $\begin{array}{l}\text { Palmar/ } \\
\text { plantar pits }\end{array}$ & $\mathrm{N}$ & $\mathrm{N}$ & $\mathrm{N}$ & $\mathrm{Y}$ \\
\hline $\begin{array}{l}\text { PTCH1 } \\
\text { mutation } \\
\text { +ve }\end{array}$ & Y & $\mathrm{N}$ & NT & NT \\
\hline $\begin{array}{l}\text { SUFU } \\
\text { mutation } \\
\text { +ve }\end{array}$ & $N$ & Y & NT & NT \\
\hline
\end{tabular}

This article is protected by copyright. All rights reserved. 
Table 5: Description of mutations in this cohort along with salient phenotypic features

\begin{tabular}{|c|c|c|c|c|c|c|c|c|}
\hline \multirow[t]{2}{*}{ Mutation } & \multicolumn{8}{|c|}{ Clinical Features } \\
\hline & Proband/FDR* & $\begin{array}{l}\text { Current } \\
\text { Age }\end{array}$ & $\begin{array}{l}\text { No. of } \\
\text { BCCs }\end{array}$ & $\begin{array}{c}\text { No. of } \\
\text { keratocysts }\end{array}$ & $\begin{array}{l}\text { Palmar } \\
\text { or } \\
\text { plantar } \\
\text { pits }\end{array}$ & $\begin{array}{c}\text { Falx } \\
\text { calcification }\end{array}$ & Macrocephaly & Other \\
\hline $\begin{array}{l}\text { PTCH1:c.3152G>A } \\
\text { (p.W1051X) in exon } 18\end{array}$ & Proband & $\begin{array}{l}\text { Died at } \\
70\end{array}$ & 9 & 5 & Yes & No & Yes & $\begin{array}{l}\text { Lung cancer } \\
\text { (smoker), } \\
\text { neurofibroma of } \\
\text { stomach }\end{array}$ \\
\hline $\begin{array}{l}\text { PTCH1:c.3152G>A } \\
\text { (p.W1051X) in exon } 18\end{array}$ & FDR of above & 23 & 0 & 4 & Yes & Yes & No & Craniosynostosis \\
\hline $\begin{array}{l}P T C H 1: c .3152 G>A \\
\text { (p.W1051X) in exon } 18\end{array}$ & FDR of above & 26 & 15 & 3 & Yes & Yes & No & Telecanthus \\
\hline $\begin{array}{l}\text { PTCH1:c. } 2460 C>A \\
\text { (p.Y820X) } \\
\text { NM_000264.3 in exon } \\
15\end{array}$ & Proband & 46 & 190 & 0 & No & $\mathrm{N} / \mathrm{A}$ & No & $\begin{array}{l}2 \text { SCCS }^{\#} \text { (high } \\
\text { occupational sun } \\
\text { exposure), } \\
\text { unilateral post } \\
\text { axial polydactyly, } \\
\text { speech impairment }\end{array}$ \\
\hline $\begin{array}{l}\text { PTCH1: c.202-2A>G, } \\
\text { NM_000264.3 }\end{array}$ & Proband & 27 & 35 & 14 & Yes & Yes & Yes & $\begin{array}{l}\text { Bifid ribs, Sprengel } \\
\text { deformity, midface } \\
\text { hypoplasia }\end{array}$ \\
\hline $\begin{array}{l}0.7 \mathrm{Mb} \text { del in } \\
\text { chromosome } 9 \mathrm{q} 22.32 \\
\text { involving PTCH1 and } 5 \\
\text { other genes }\end{array}$ & Proband & 15 & 0 & 5 & Yes & Yes & Yes & $\begin{array}{l}\text { Mild gross motor } \\
\text { developmental } \\
\text { delay }\end{array}$ \\
\hline $\begin{array}{l}\text { SUFU: c. } 756+1 G>A \text { in } \\
\text { intron } 6\end{array}$ & Proband & 57 & 3 & 0 & No & No & Yes & $\begin{array}{l}\text { Benign facial } \\
\text { folliculosebaceous } \\
\text { hamartomas, two } \\
\text { children died of } \\
\text { medulloblastoma } \\
\text { under the age of } \\
\text { two }{ }^{1}\end{array}$ \\
\hline $\begin{array}{l}\text { SUFU:C. } 1365+2 T>A \text { in } \\
\text { intron } 11^{\wedge}\end{array}$ & Proband & 62 & 150 & 0 & No & Yes & Yes & $\begin{array}{l}\text { Childhood } \\
\text { medulloblastoma } \\
\text { in a grandson }\end{array}$ \\
\hline
\end{tabular}

*FDR= First Degree Relative

\#SCCs=Squamous Cell Carcinomas

^This canonical splice site mutation 2 base pairs after the end of exon 11 of SUFU is uniformly predicted to completely abolish the donor splice site of intron 11, leading to synthesis of abnormal protein. As this is a novel mutation with no previous documentation of it's functional impact, RNA studies are currently under way to fully understand the functional consequences of this mutation

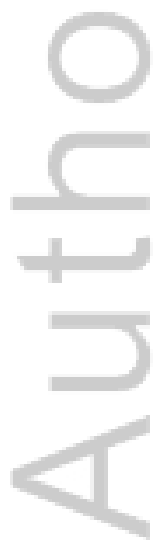


Table 6: Characteristics of PTCH1 mutation +ve and mutation -ve patients

\begin{tabular}{|lccc|}
\hline & $\begin{array}{r}\text { PTCH1 +ve (n=6) } \\
\text { Patients with BCCs }\end{array}$ & $\begin{array}{c}\text { PTCH1 -ve (n=7) } \\
\text { (\%) }\end{array}$ & $\begin{array}{c}\text { p-value } \\
5 / 7(71.4)\end{array}$ \\
$\begin{array}{l}\text { Median number of } \\
\text { BCCs (IQR) }\end{array}$ & $12(0-35)$ & $40(3-70)$ & 0.572 \\
$\begin{array}{l}\text { Patients with jaw } \\
\text { cysts (\%) }\end{array}$ & $5 / 6(83.3)$ & $2 / 7(28.6)$ & 0.103 \\
$\begin{array}{l}\text { Patients with } \\
\text { palmar/plantar pits } \\
\text { (\%) }\end{array}$ & $5 / 6(83.3)$ & $0 / 7(0)$ & 0.005 \\
$\begin{array}{l}\text { Patients with } \\
\text { calcification of the } \\
\text { falx (\%) }\end{array}$ & $2 / 2(100)$ & $3 / 6(50.0)$ & 0.464 \\
$\begin{array}{l}\text { Family history of } \\
\text { Gorlin (\%) }\end{array}$ & $3 / 5(60)$ & $3 / 6(50.0)$ & 1.000 \\
Macrocephaly & $2 / 3(66.7)$ & $3 / 6(50.0)$ & 1.000 \\
\hline
\end{tabular}

${ }^{\#}$ Four of these 6 individuals were probands and 2 were relatives who underwent confirmatory genetic testing

*Two of these patients were identified to have a SUFU mutation.

The varying denominator represents the subgroup of patients in whom testing was undertaken and in whom the phenotypic information was available.

The majority of PTCH1 testing was performed through Sanger sequencing although the more recent tests were performed through next generation sequencing and Sanger verification of variants. Copy number variant analysis on all samples was undertaken either through MLPA or CGH-array based techniques by the testing laboratory. All SUFU tests were done through massively parallel sequencing with variants confirmed by Sanger sequencing in addition to QMPS or CGH-array based copy number variation analysis by the testing laboratory.

This article is protected by copyright. All rights reserved. 
Table 7: QoL scores compared with population norms

\begin{tabular}{|c|c|c|c|c|}
\hline \multicolumn{2}{|c|}{ Qol scores in Gorlin syndrome cohort } & \multicolumn{2}{|c|}{$\begin{array}{l}\text { Qol scores in general population } \\
\text { (population norms) }\end{array}$} & \multirow[t]{2}{*}{ p value } \\
\hline & $\begin{array}{l}\text { Weighted Qol } \\
\text { scores }\end{array}$ & & $\begin{array}{l}\text { Weighted } \\
\text { Qol scores }\end{array}$ & \\
\hline Overall & 0.84 & Overall & 0.80 & 0.3 \\
\hline \multicolumn{2}{|l|}{ Age ranges in years } & \multicolumn{2}{|l|}{ Age ranges in years } & \\
\hline$\leq 25$ & 0.92 & $15-24$ & 0.78 & \\
\hline$=$ & & $25-34$ & 0.82 & \\
\hline $26-50=$ & 0.84 & $35-44$ & 0.83 & \\
\hline & & $45-54$ & 0.79 & \\
\hline \multirow[t]{3}{*}{$51-70$} & 0.79 & $55-64$ & 0.80 & \\
\hline & & $65-74$ & 0.77 & \\
\hline & & $75+$ & 0.75 & \\
\hline Dimensions & & Dimensions & & \\
\hline Independent living & 0.94 & Independent living & 0.91 & 0.452 \\
\hline Relationships & 0.92 & Relationships & 0.89 & 0.473 \\
\hline Mental Health & 0.64 & Mental Health & 0.63 & 0.835 \\
\hline Coping & 0.85 & Coping & 0.81 & 0.310 \\
\hline Pain & 0.82 & Pain & 0.79 & 0.565 \\
\hline Senses & 0.89 & Senses & 0.91 & 0.500 \\
\hline
\end{tabular}

This article is protected by copyright. All rights reserved. 
Table 8: QoL characteristics

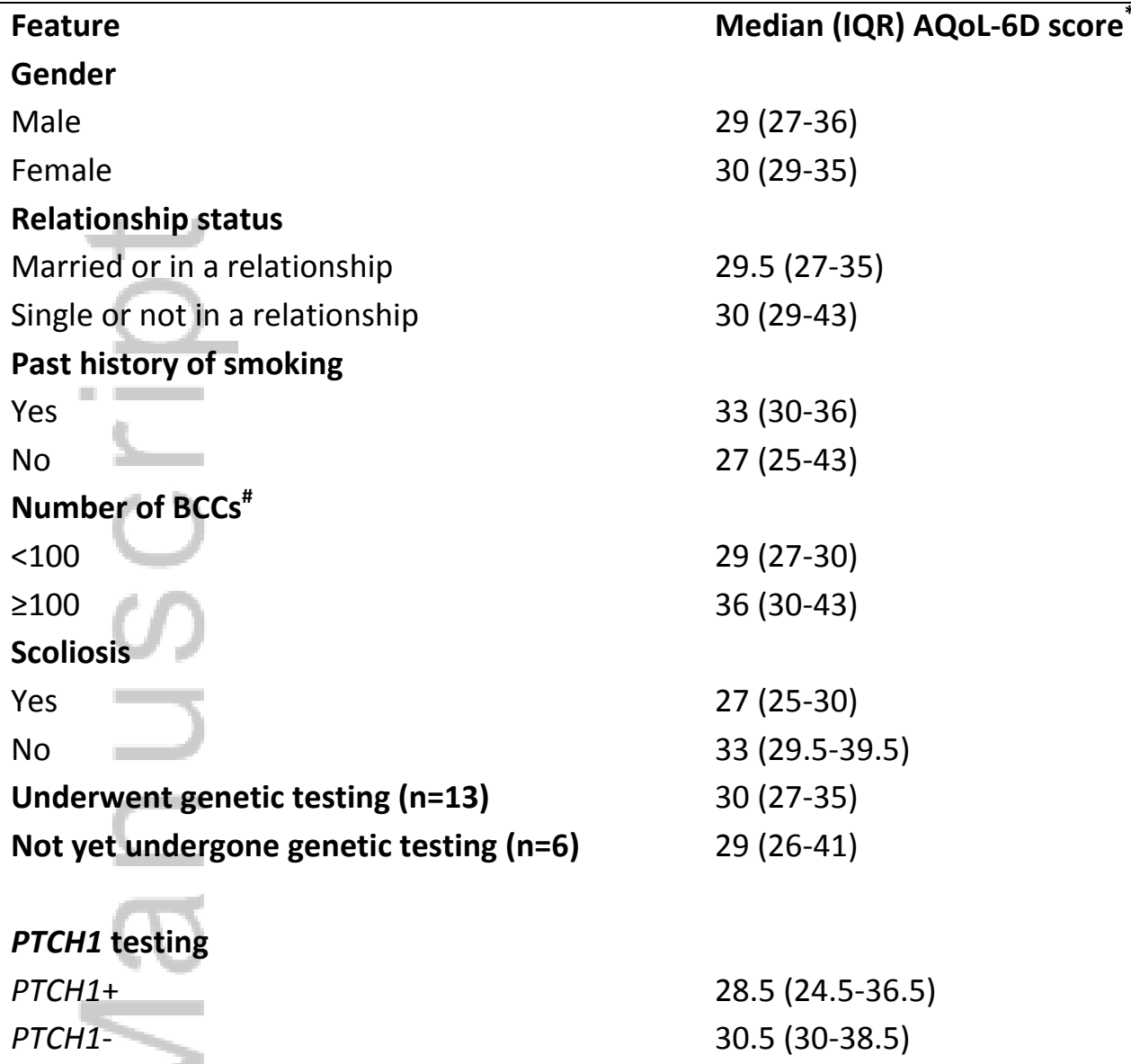

The scores used here are overall scores and not individually weighted to the various dimensions 
APPENDIX 1

Fitzpatrick skin types

\begin{tabular}{|l|l|l|l|}
\hline \multicolumn{4}{|l|}{ Fitzpatrick Skin Types } \\
\hline Skin Type & Skin Colour & Sunburn & Tan \\
\hline I II & White & Yes & No \\
\hline III & White & Yes & Minimal \\
\hline IV & White & Yes & Yes \\
\hline V & White & No & Yes \\
\hline VI & Brown & No & Yes \\
\hline
\end{tabular}

Fitzpatrick, T.B., The validity and practicality of sun-reactive skin types I through VI. Arch Dermatol, 1988. 124(6): p. 869-71.

This article is protected by copyright. All rights reserved. 


\section{University Library}

\section{- M M N E R VA A gateway to Melbourne's research publications}

Minerva Access is the Institutional Repository of The University of Melbourne

\section{Author/s:}

Huq, AJ;Bogwitz, M;Gorelik, A;Winship, IM;White, SM;Trainer, AH

Title:

Cohort study of Gorlin syndrome with emphasis on standardised phenotyping and quality of life assessment

\section{Date:}

2017-06-01

\section{Citation:}

Huq, A. J., Bogwitz, M., Gorelik, A., Winship, I. M., White, S. M. \& Trainer, A. H. (2017). Cohort study of Gorlin syndrome with emphasis on standardised phenotyping and quality of life assessment. INTERNAL MEDICINE JOURNAL, 47 (6), pp.664-673. https:// doi.org/10.1111/imj. 13429 .

Persistent Link:

http://hdl.handle.net/11343/292992 